\title{
TERRITÓRIO ETNOEDUCACIONAL CONE SUL E EDUCAÇÃO DIFERENCIADA INDÍGENA: INTERCULTURALIDADE E RESISTÊNCIA
}

\author{
ETHNO-EDUCATIONAL TERRITORIES CONE SUL AND DIFFERENTIATED INDIGENOUS EDUCATION: \\ INTERCULTURALITY AND RESISTANCE
}

\section{RESUMO}

A Constituição Federal (1988) reconheceu a condição étnica particular dos povos indígenas; garantiu-lhes o direito ao seu território e a educação diferenciada, que significa educação específica e bilíngue, respeitando a língua materna. Os "territórios etnoeducacionais" (TEE) foram criados para garantir a educação diferenciada aos diferentes povos indígenas, apenas em 2009, visando cumprir a Constituição e organizar os órgãos públicos e governos em bases territoriais definidas pelas condições étnico-culturais. A escola assumiria papel fundamental na construção da etnoterritorialidade, visando promover autonomia desses Povos, por meio da implementação da educação diferenciada e referenciada em cada cultura, na relação com as demais culturas e pela interculturalidade; envolvendo acesso ao conhecimento e políticas educacionais e a formação profissional e de professores indígenas para lecionarem nessas escolas, para seu povo. No Mato Grosso do Sul, o "TEE Cone Sul" congrega a maior população Guarani/Kaiowá do Brasil, vivendo em aldeias, reservas, cidades, acampamentos e áreas de retomadas; convivendo com outros Povos, como os Terena, mas, fundamentalmente, com o preconceito e a violência, na disputa pela terra, com proprietários de terras e o agronegócio. Nossa análise permite refletir sobre o sentido dos TEE, enquanto campo de resistência possível, considerando a existência de políticas públicas avançadas, mas que ainda estão engatinhando na valorização desses povos enquanto cidadãos etnicamente diferentes, submetidos a governos mais defensores dos interesses privados do que da Lei Magna; situação que se agravou com o Golpe de 2016.

Palavras-chave: Política Pública; Educação Diferenciada Indígena; Territórios Etnoeducacionais; Etnoterritório; Território Etnoeducacional Cone Sul; Mato Grosso do Sul.

\section{ABSTRACT}

The federal Constitution (1988) acknowledge the particular ethnic status of indigenous peoples; guaranteed their right to their territory and differentiated education, which means specific and bilingual education, respecting the mother tongue. The "ethno-educational territories" (TEE) were created only in 2009 to guarantee differentiated education to the different indigenous people, intending to obey the Constitution and organize public agencies and governments on territorial bases defined by ethnic and cultural conditions. The school would take on a fundamental role in the construction of ethnoterritoriality, aiming to promote autonomy for these People, through the implementation of differentiated education and referenced in each culture, in relation to other cultures and interculturality, involving access to knowledge and educational policies and the professional training and of indigenous teachers to work in indigenous schools teaching their people. In Mato Grosso do Sul, the "TEE Cone Sul" has the largest Guarani/Kaiowá population in Brazil, living in villages, reserves, cities, camps and areas of land repossession, coexisting with other people, such as the Terena, but, fundamentally, with prejudice and violence, in the dispute over land with landowners and agribusiness. Our analysis allows us to reflect on the meaning of TEE as possible resistance field, considering the existence of advanced public policies, but that is still crawling in the valorization of these peoples as ethnically different citizens, submitted to governments more defenders of the private interests than of the Magna Law, which was aggravated by the 2016 coup.

Keywords: Public Police; Differentiated Indigenous Education; Ethno-educational Territories; Cone Sul Ethno-educational Territories; Mato Grosso do Sul.

\section{Silvana de Abreu ${ }^{\text {a }}$}

${ }^{a}$ Universidade Federal da Grande Dourados (UFGD), Dourados, MS, Brasil

DOI: $10.12957 /$ geouerj.2020.43518

Correpondência: sabreu@ufgd.edu.br

Recebido em: 24 jun. 2019

Aceito em: 26 mar.2020 


\section{INTRODUÇÃO}

A condição de luta dos povos indígenas pelo direito de viverem ao seu modo é exemplo de resistência e não significa que desejam retomar ao modo de vida tradicional. No processo de relações com os valores e costumes entre diferentes povos indígenas e, sobretudo, com a sociedade não índia, as transformações vividas têm conduzido à luta pelo direito a interculturalidade ${ }^{1}$ e autonomia. Nesse sentido, a luta é pelo acesso e troca entre as diferentes culturas, com garantia de uso e aprendizado da língua materna e formação bilíngue; incorporação de técnicas de produção e acessos a (alguns) confortos disponíveis aos não índios; direito a saúde e educação diferenciada; subsistência de seus povos, combate a fome e a pobreza absoluta, ainda muito presente em comunidades indígenas e acesso ao conhecimento produzido e a formação de sujeitos na/para a sociedade atual. Segundo Bakes (2014, p.14):

Os povos indígenas, desde o período da colonização, vêm lutando de múltiplas formas em defesa de suas identidades. Na produção das identidades indígenas, depois da invasão europeia, a escola tem tido um papel central - num primeiro momento, imposta pelo colonizador com o intuito de eliminar essas identidades e, atualmente, protagonizada pelos indígenas, com o objetivo de fortalecê-las. Com base em Candau e Russo (2010), podemos dizer que há quatro momentos distintos da educação escolar indígena no Brasil. O primeiro inicia-se no período colonial e vai até as primeiras décadas do século XX; caracteriza-se pela "[...] violência etnocêntrica explícita de imposição da cultura hegemônica sobre as populações indígenas" (CANDAU; RUSSO, 2010, p. 155), ou seja, a escola servia para eliminar o indígena, sua cultura, sua língua. $O$ segundo momento, das primeiras décadas do século XX até a década de 1970, caracteriza-se pela assimilação cultural, com o intuito de construir um Estado homogêneo. Nessa perspectiva, o indígena deveria ser assimilado pela cultura nacional para fazer parte da massa trabalhadora, pois o país estava se inserindo no modelo urbano/industrial. Nesse período, começam a surgir escolas bilíngues, mas quase sempre a língua materna era vista como elemento de transição para facilitar a assimilação cultural. O terceiro momento, nas décadas de 1970 e 1980, caracteriza-se pela emergência de experiências alternativas ligadas a lideranças comunitárias e à Igreja Católica Progressista, preocupadas em fortalecer a cultura e a identidade indígena. O quarto momento inicia-se no final dos anos 1980 e continua vigente; caracteriza-se pela defesa de uma escola intercultural, bilíngue e diferenciada, propondo um diálogo entre as culturas. Desse momento, a Constituição de 1988 é apontada tanto pelos povos indígenas quanto pelos pesquisadores desse campo como um marco decisivo para o direito a uma educação específica, diferenciada, incluindo o ensino na língua materna e os processos próprios de aprendizagem. Ressalte-se que se tratou não de uma dádiva do Estado brasileiro, mas de uma conquista, fruto do movimento indígena. Com essa Constituição e o aparato legal que vem sendo conquistado, abrem-se novas possibilidades, voltadas para as cosmologias de cada povo, assim contribuindo para o processo de afirmação identitária. (destaque nosso)

A contextualização expressa em Bakes (2014), permite compreender a apropriação da escola, pelos povos indígenas, como resistência. A escola diferenciada e a educação escolar indígena foram conquistas dos movimentos sociais indígenas, organizados em torno da luta pela sua terra e sua cultura. Nesse sentido estão colocados alguns desafios importantes, tais como: 1) garantir a formação de professores indígenas em nível médio e também em nível superior e 2) criar escolas indígenas para educação básica específica para as

\footnotetext{
${ }^{1}$ A interculturalidade comparece em vários autores como relação decolonial, no sentido da superação homogeneizadora que a escola assume desde o "descobrimento" mas que encontra possibilidades de legitimar-se, sob o marco legal da Constituição Brasileira de 1988. Encontramos em Aguilera Urquiza e Nascimento (2010) análises que nos permite compreender a interculturalidade pela possibilidade de ressignificação da escola indígena e "seus aprendizados" sob a perspectiva sociocultural e a definição de fronteiras entre saberes que são do índio e do não-índio, mas também de outros índíos, entre si. Referendando autonomia para que os povos possam ser brasileiros sem deixarem de ser índios: Guarani, Kaiowá, Guató, Terena e todos que puderem ser. A interculturalidade implica em reconhecimento da diferença e da diversidade cultural que isso significa.
} 
comunidades indígenas, com professores indígenas e ênfase na valorização dos conhecimentos tradicionais e identitários. Concorda-se com o autor e apreende-se que a luta pela sobrevivência desses povos os levou a escola diferenciada.

Apoiada nos anos oitenta do século XX, dentro do contexto mundial das organizações humanitárias e de defesa ao meio ambiente, projeta-se a resistência e luta dos trabalhadores sem terra, dos povos da floresta e dos movimentos sociais e sindicais em busca da redemocratização, da ampliação dos direitos sociais e de eleições livres no Brasil; processo que conduziu à instalação da Assembleia Nacional Constituinte (na segunda metade dos anos oitenta) com o objetivo de refazer, com base nos princípios da democracia e direito à cidadania a todos os cidadãos brasileiros, uma nova Constituição Brasileira² (promulgada em 1988) que ficaria conhecida como "Constituição Cidadã".

Entre os direitos consolidados, no Título VIII, Da Ordem Social, Cap. VIII, Dos Índios, estão assegurados o respeito à organização social, aos seus costumes, as diferentes línguas, crenças e tradições. Em seu artigo 210, inclusive, está expresso "o respeito a utilização de suas línguas maternas e processos próprios de aprendizagem". Da mesma forma, a nova Carta Magna definiu sobre o direito às terras a partir da constituição dos chamados "direitos originários"; ou seja, o reconhecimento do direito ao território, anterior ao Estado Brasileiro e o reconhecimento histórico do processo de expropriação desses povos de suas terras. A demarcação das terras indígenas, prevista para acontecer em cinco anos, portanto, entre 1989 e 1993 , adentrou o século XXI e ainda é, em 2019, um processo sob conflitos. Assim, apesar da garantia e do reconhecimento do Índio existir como tal estarem previstos na Constituição Brasileira, desde 1988, a realização dessa condição se mantém ainda sob movimento de luta, pelos diferentes povos indígenas espalhados pelo território nacional.

Em 2004, o Presidente Luiz Inácio Lula da Silva editou o Decreto 5051³, em 19/04/2004, chamando a responsabilidade para o poder executivo sobre a Convenção nำ169, da Organização Internacional do Trabalho (OIT), sobre os povos indígenas e tribais, adotada em Genebra, em 27 de Junho de 1989:

Considerando que o Congresso Nacional aprovou, por meio do Decreto Legislativo no 143, de 20 de junho de 2002, o texto da Convenção no 169 da Organização Internacional do Trabalho - OIT sobre Povos Indígenas e Tribais, adotada em Genebra, em 27 de junho de 1989; Considerando que o Governo brasileiro depositou o instrumento de ratificação junto ao Diretor Executivo da OIT em 25 de julho de 2002; Considerando que a Convenção entrou em vigor internacional, em 5 de setembro de 1991, e, para o Brasil, em 25 de julho de 2003, nos termos de seu art. 38.

\footnotetext{
2 Para consultar CF ver: https://www2.senado.leg.br/bdsf/bitstream/handle/id/518231/CF88_Livro_EC91_2016.pdf (acessado em 22/11/2018)

${ }^{3}$ http://www.planalto.gov.br/ccivil 03/ ato2004-2006/2004/decreto/d5051.htm (Acessado em 22/11/2018)
} 


\section{DECRETA :}

Art. 1o A Convenção no 169 da Organização Internacional do Trabalho - OIT sobre Povos Indígenas e Tribais, adotada em Genebra, em 27 de junho de 1989, apensa por cópia ao presente Decreto, será executada e cumprida tão inteiramente como nela se contém.

Art. 2o São sujeitos à aprovação do Congresso Nacional quaisquer atos que possam resultar em revisão da referida Convenção ou que acarretem encargos ou compromissos gravosos ao patrimônio nacional, nos termos do art. 49, inciso I, da Constituição Federal.

Sob a Convenção 169/1989, referenciada nesse Decreto 5.051/2004, em seus Artigos 6 e 70 vincula-se ao direito de participação e de consentimento dos povos indígenas, toda ação que possa vir afetá-los diretamente, inclusive projetos nacionais de desenvolvimento e que influenciem na ocupação territorial, na cultura e modo de viver das comunidades indígenas. Veja-se parte do Artigo 70 da OIT/1989 expresso no Decreto supracitado:

1. Os povos interessados deverão ter o direito de escolher suas, próprias prioridades no que diz respeito ao processo de desenvolvimento, na medida em que ele afete as suas vidas, crenças, instituições e bemestar espiritual, bem como as terras que ocupam ou utilizam de alguma forma, e de controlar, na medida do possível, o seu próprio desenvolvimento econômico, social e cultural. Além disso, esses povos deverão participar da formulação, aplicação e avaliação dos planos e programas de desenvolvimento nacional e regional suscetíveis de afetá-los diretamente. (...)

Considerando, ainda, o Artigo 4ำ da OIT $/ 1989^{4}$, ficam esclarecidos os Princípios que instituíram o Protocolo de Consulta Prévia dos Povos indígenas como ação preventiva e de defesa dos direitos dos Povos indígenas:

Os princípios orientadores do direito à consulta são os seguintes:

1. Oportunidade. 0 processo de consulta é realizado antes da medida legislativa ou administrativa a ser adotada pelas entidades estatais. 2. Interculturalidade. O processo de consulta é realizado reconhecendo, respeitando e adaptando-se às diferenças existentes entre as culturas e contribuindo para o reconhecimento e o valor de cada uma delas. 3. Boa fé. As entidades do Estado analisam e avaliam a posição dos povos indígenas ou indígenas durante o processo de consulta, em um clima de confiança, colaboração e respeito mútuo. O Estado e os representantes das instituições e organizações de povos indígenas ou indígenas têm o dever de agir de boa fé e são proibidos de todo o proselitismo partidário e conduta antidemocrática. 4. Flexibilidade. A consulta deve ser realizada por meio de procedimentos adequados ao tipo de medida legislativa ou administrativa a ser adotada, bem como tendo em conta as circunstâncias e características especiais dos povos indígenas ou indígenas envolvidos. 5. Prazo razoável. O processo de consulta é realizado considerando prazos razoáveis que permitem às instituições ou organizações representativas dos povos indígenas ou indígenas conhecer, refletir e fazer propostas concretas sobre as medidas legislativas ou administrativas a serem consultadas. 6. Ausência de coerção ou condicionamento. A participação de povos indígenas ou indígenas no processo de consulta deve ser realizada sem qualquer coerção ou condicionamento. 7. Informações oportunas. Os povos indígenas ou indígenas têm o direito de receber das entidades estatais todas as informações necessárias para que possam expressar seu ponto de vista, devidamente informado, sobre a medida legislativa ou administrativa a ser consultada. O Estado tem a obrigação de fornecer esta informação desde o início do processo de consulta e com a devida antecipação. (grifo nosso)

\footnotetext{
${ }^{4}$ http://www.mpf.mp.br/atuacao-tematica/ccr6/documentos-e-publicacoes/protocolos-de-consulta-dos-povos-indigenas/docs/semtitulo-1.pdf (acessado em 22/11/2018)
} 
Durante o governo do presidente Luiz Inácio Lula da Silva, por meio do Decreto 6.861, de 27/05/2009, a educação escolar indígena diferenciada foi finalmente reconhecida e criada, como previsto na Constituição de 1988, e se organizaria na forma de "Territórios Etnoeducacionais" (TEE), cujas ações planejadas devem ser apoiadas pelo Governo Federal, por meio do Ministério da Educação:

Art. 6o Para fins do apoio de que trata o art. 5o, a organização territorial da educação escolar indígena será promovida a partir da definição de territórios etnoeducacionais pelo Ministério da Educação, ouvidos:

I - as comunidades indígenas envolvidas;

II - os entes federativos envolvidos;

III - a Fundação Nacional do Índio - FUNAl;

IV - a Comissão Nacional de Educação Escolar Indígena;

$\mathrm{V}$ - os Conselhos Estaduais de Educação Escolar Indígena; e

VI - a Comissão Nacional de Política Indigenista - CNPI.

Parágrafo único. Cada território etnoeducacional compreenderá, independentemente da divisão político-administrativa do País, as terras indígenas, mesmo que descontínuas, ocupadas por povos indígenas que mantêm relações intersocietárias caracterizadas por raízes sociais e históricas, relações políticas e econômicas, filiações lingüísticas, valores e práticas culturais compartilhados. ${ }^{5}$

Os TEE, ainda que por meio de Decreto, se constituíram na referência para a implementação de uma política governamental para fazer cumprir o direito constitucional previsto de "processos próprios de aprendizagem" aos povos indígenas. De acordo com Rossato (2017, p.07):

Historicamente, a ideia dos Territórios Etnoeducacionais vem sendo amadurecida desde 1990, por instituições indigenistas e universidades. Primeiro pensaram na criação de 'distritos de educação indígena' com uma estrutura federalizada. Esta proposta acabou se desdobrando numa outra iniciativa que deu origem aos 'distritos de saúde indígena'. De qualquer forma, as propostas distritais são, aparentemente, próximas à do 'etnoterritório educacional'. No entanto, os TEEs organizam e articulam as várias instâncias e níveis governamentais num espaço territorial de acordo com as proximidades étnicas e culturais, sem eliminar as responsabilidades das diversas instâncias governamentais. (destaque nosso)

Não é, portanto, tarefa fácil a definição e implantação dos TEE, que sobrepõe limites municipais e envolve todos os entes governamentais (municipais, estaduais e federais) obrigatoriamente e as comunidades indígenas opcionalmente. Assim, apenas os indígenas podem optar por não participar do "pacto do TEE". Ainda, segundo a autora :

\begin{abstract}
administrar e atuar na gestão da escola indígena a partir desse novo paradigma exige uma gestão compartilhada, ou seja: ouvir, respeitar, construir consensos nas decisões e na execução de ações que atendam aos interesses e necessidades indígenas e estejam dentro das leis nacionais que regem a educação brasileira, na especificidade da escola diferenciada. (ROSSATO, 2017, p.08)
\end{abstract}

É mister reconhecer que o passo dado em 2009 foi significativo, contudo não se tratava apenas de definir os TEE, haveria ainda que reconhecer os territórios indígenas, também previstos na Constituição de 1988. Haveria que reconhecer os próprios povos indígenas como tal.

\footnotetext{
5 Ver: http://legislacao.planalto.gov.br/legisla/legislacao.nsf/Viw Identificacao/DEC\%206.861-2009?OpenDocument (acessado em 12/11/2018). Ver ainda: http://www.planalto.gov.br/ccivil 03/ Ato2007-2010/2009/Decreto/D6861.htm (acessado 22/11/2018)
} 
Assim como a Constituição de 1988, os TEE criados são apenas "gatilhos" para desencadeamento de ações articuladas e políticas governamentais específicas como: (2003) Criação do Programa Nacional de Alimentação Escolar Indígena; (2005) Criação do Projeto Inovador de Fortalecimento de Escolas de Ensino Médio Indígena; (2009) Criação dos Territórios Etnoeducacionais, com gestão compartilhada para o desenvolvimento da educação intercultural indígena; (2013) Programa Bolsa Permanência MEC, que foi instituído a partir da articulação entre a FUNAI e o MEC, como forma de suceder e qualificar o benefício de apoio financeiro, custeado até então exclusivamente pela Fundação a estudantes universitários indígenas; (2013) Criação do Programa Nacional dos Territórios Etnoeducacionais Indígenas (PNTEE) entre outras políticas governamentais, em diferentes áreas (infraestrutura, saúde etc). ${ }^{6}$

O Instituto Brasileiro de Geografia e Estatística7, com base no censo de 2010, sistematizou dados representativos sobre a população indígena no País. A Figura 01 representa o avanço da coleta de informações de um órgão de pesquisa nacional, frente ao reconhecimento de outras nações, outros povos, no interior do País, mesmo que se esteja longe da incorporação desse reconhecimento enquanto valor cultural nacional e, fundamentalmente, de superação dos preconceitos.

Figura 1. Mapa da distribuição da população Indígena do Brasil, independente de residência em Terra Indígena. Fonte: IBGE - Censo de 2010. http://www.ibge.gov.br

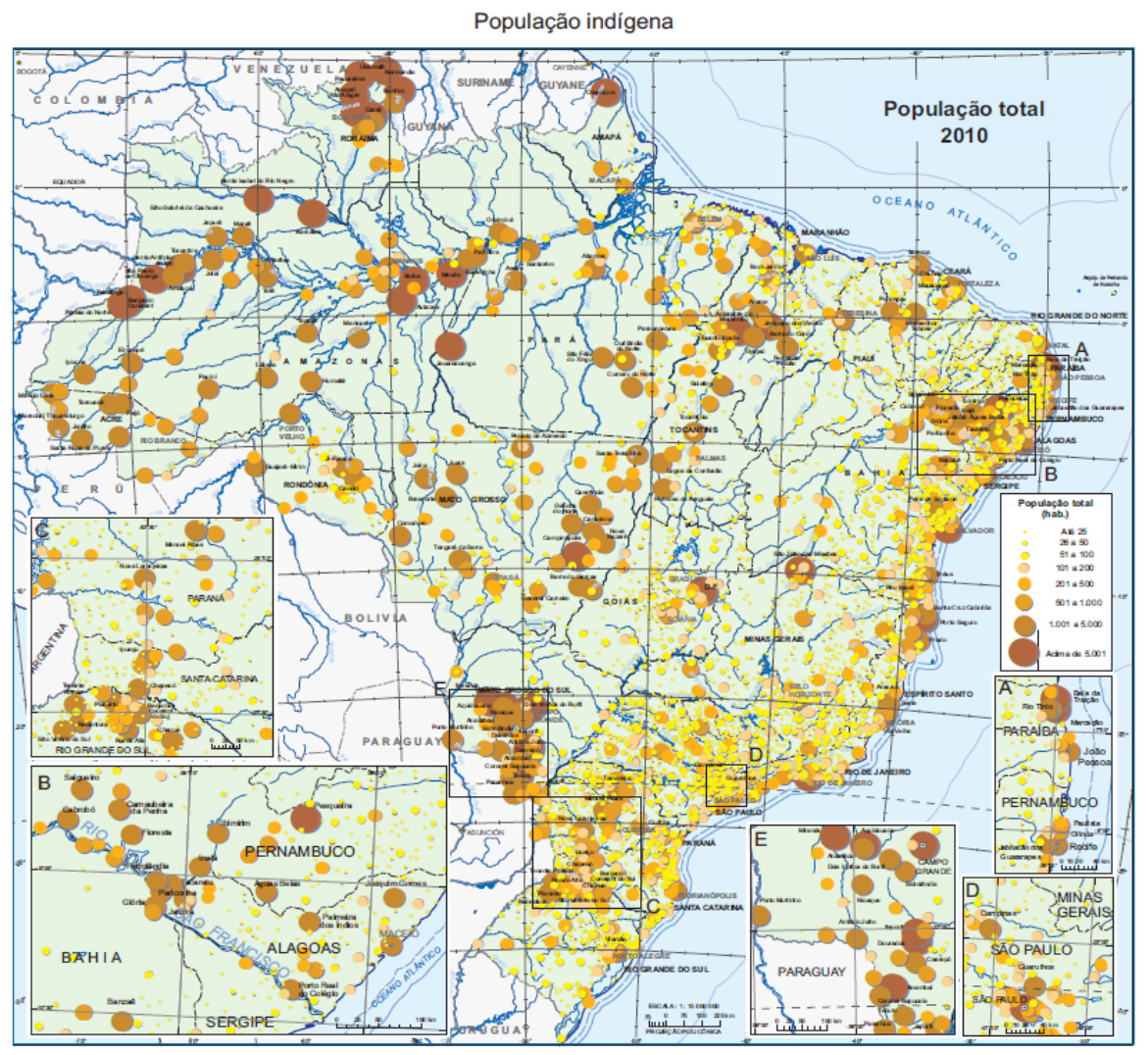

\footnotetext{
${ }^{6}$ Ver: http://www.funai.gov.br/index.php/nossas-acoes/politica-indigenista?start=13\# (Acesso 22/11/2018)

${ }^{7}$ Ver http://www.funai.gov.br/index.php/indios-no-brasil/o-brasil-indigena-ibge (acesso 22/11/2018)
} 
Assim, há muitas terras em processo de legalização, com diferentes situações, mas pelo menos $23 \%$ ainda estão em estudo. Observa-se, que das áreas em questão, entre as que se encontram "em estudo", pelo menos treze (13) delas são de povos Guarani/Kaiowá, situação que se pode compreender na lógica da colonização e integração do território realizada e pela situação dos Povos Guarani, em termos populacionais, submetidos a confinamento em Reservas e/ou expropriação de seu tekohá ${ }^{8}$, para dar lugar à produção agropecuária, principalmente a monocultura. Assim, segundo a própria FUNAI $^{9}$, as terras indígenas regularizadas, representam apenas 1,6\% de toda a superfície do estado de Mato Grosso do Sul e pelo menos 20,6\% da população indígena não se encontra em área indígena.

A demarcação de terras indígenas no Mato Grosso do Sul é inexpressiva em termos de representação, considerando a escala nacional, e se apresenta sob terras descontínuas, com áreas que são até difíceis de representar em escala nacional, sem contar que é significante de questões ainda em debate e sem condições de resolução futura e a curto prazo; antes pelo contrário, a conjuntura que se estabeleceu desde o impeachment da presidenta Dilma Roussef, em 2016, tem ampliado as dificuldades para essas populações, sobretudo com a eleição presidencial de 2018, que elegeu Jair Bolsonaro para o mandato presidencial 20192022. Diante da representação dessa população indígena, em nível estadual e nacional, é possível compreender a problemática que cerca a questão da terra indígena, seja das áreas demarcadas, seja as não demarcadas e sob conflitos entre indígenas e proprietários de terras.

Segundo Lacoste (1988), os mapas costumam ter um papel importante no sentido de representar informações. Seja para garantia de estratégias de guerras ou de localização de riquezas, que são preocupações de uma sociedade de relações de produção mais complexas e concentradora; seja para localizar/representar a significativa e resistente população indígena no Brasil e/ou no Mato Grosso do Sul. Aspectos, que sob conhecimento e controle, podem se transformar em instrumentos de luta e de ação para movimentos sociais e para o Estado (nesse caso; os governos). Há que se considerar que as representações em pauta, em consonância com movimentos sociais de luta por direitos constitucionais (ou mesmo até por conta dos movimentos sociais) podem contribuir para legitimar reivindicações e fomentar ações.

O censo realizado pelo IBGE, em 2010, assim como as representações cartográficas e dados dele derivados expressam uma outra condição, possível de ser estabelecida; qual seja, a sistematização e representação de informações geradas, por meio de um órgão oficial, como é o IBGE, sob metodologia reconhecida, e que dá conta de expor a situação e condição vivida por essas populações (em nível nacional, por estado, por município), como nunca antes se conseguiu fazer, em um mesmo momento e documento.

\footnotetext{
${ }^{8}$ TEKO = modo de ser e de viver $H A ́$ = lugar. O tekohá seria então o espaço de perambulação necessário para exercer o modo de vida, as relações dos sujeitos entre si e produção de sua existência.

9 Ver: http://www.funai.gov.br/index.php/nossas-acoes/demarcacao-de-terras-indigenas?start=1\# (acessado em 23/11/2018)
} 
Após o Decreto de criação dos TEE, certamente o Censo oficial para os povos indígenas não foi uma ação isolada. Há que se concordar com Yves Lacoste!

A territorialidade etnoeducacional, aqui em discussão específicamente, considerando argumentos de Mota (2011), consolida-se em reterritorização, que deriva do sofrido processo de desterritorilização e/ou territorialização precária a que foram submetidos os Indios, mas que não se resolve imediatamente sob a forma de legislações e normativos, nem mesmo pela Carta Magna. Há que se considerar, inclusive, que os dois TEE do Mato Grosso do Sul, assim como nos demais estados da federação, envolvem a existência e o direito aos diferentes povos indígenas. Aspectos que necessitam ser compreendidos e considerados pelos diferentes sujeitos envolvidos. ${ }^{10}$

Sem dúvida, as relações historicamente construídas entre índios e não índios estão muito longe de serem sequer compensadas com ações como a criação dos TEE, por exemplo. Tais relações, além de resultarem em subserviência, consolidaram um movimento de genocídio de muitos dos povos indígenas no Brasil. No Mato Grosso do Sul, as ultimas duas décadas do século XX foram marcadas por alto índice de suicídios entre jovens e adultos Guarani/Kaiowá e altos índices de mortalidade infantil por subnutrição, situação que tomou proporções mundiais, encorajando pesquisas nas universidades e movimentos sociais e humanitários, que trouxeram à tona - denunciando ao mundo - a condição de miserabilidade em que viviam os Povos Guarani/Kaiowá no Estado.

O movimento pela educação diferenciada indígena e pela escola indígena tem lastro nos movimentos sociais vinculados à defesa desses e outros povos, dando visibilidade aos invisíveis e expondo a "questão indígena" no Brasil. Esses movimentos associaram a luta pela defesa de educação para as populações indígenas, como articulação para conquistar a autonomia, reconhecimento e direito a existência de diversidade de povos, superando a condição nacionalista de influência norte-americana e encontrou na conjuntura de retomada democrática e dos movimentos sociais dos anos oitenta, condições de afirmação pela Constituição.

Segundo Sousa (2013, p.41/42), somente em 1999 o termo "educação escolar indígena" é oficializado a partir das Diretrizes Curriculares Nacionais da Educação Escolar Indígena e da criação da "escola diferenciada indígena". Dispondo sobre a cronologia dos avanços para a temática, a autora demonstra, que até meados da primeira década do século XXI, pouco existia de avanço na questão. Eram secretarias estaduais e municipais desarticuladas, gerindo as escolas da mesma forma e princípios pedagógicos das escolas urbanas,

10 Ver http://www.mpf.mp.br/atuacao-tematica/ccr6/documentos-epublicacoes/artigos/docs/artigos/docs artigos/artigo protecao constitucional.pdf 
reproduzindo a interpretação e diretrizes pedagógicas do MEC sobre as escolas indígenas, desconectados da especificidade de cada povo indígena e suas diferentes cosmologias.

TEE Cone Sul: diálogos e representações de suas "gentes"

A criação dos Territórios Etnoeducacionais, como nos reportamos, aconteceu por meio do Decreto 6.861/2009 e reconhecemos como avanço importante, por incorporar o território como relações e não apenas como base física (Figura 02).

De 1988 a 2009, vinte e um anos se passaram. De acordo com Sousa (2013), trata-se “... da incorporação de um novo papel que o território assume, aliado a educação, na luta por autonomia e autoafirmação étnica"(SOUSA, 2013, p.60), para além da demarcação de terras. Concordamos com a assertiva, mas também que a "construção de territórios etnoeducacionais reestabelece grande parte do significado e da força do território como espaço vital da existência indígena." (SOUSA, 2013, p.60) (grifo nosso)

Figura 2. Mapa dos Territórios Etnoeducacionais pactuados. Fonte: http://6ccr.pgr.mpf.mp.br/institucional/grupos-detrabalho/educacao/documentos/mapa-dos-territorios-etnoeducacionais-pactuados/view

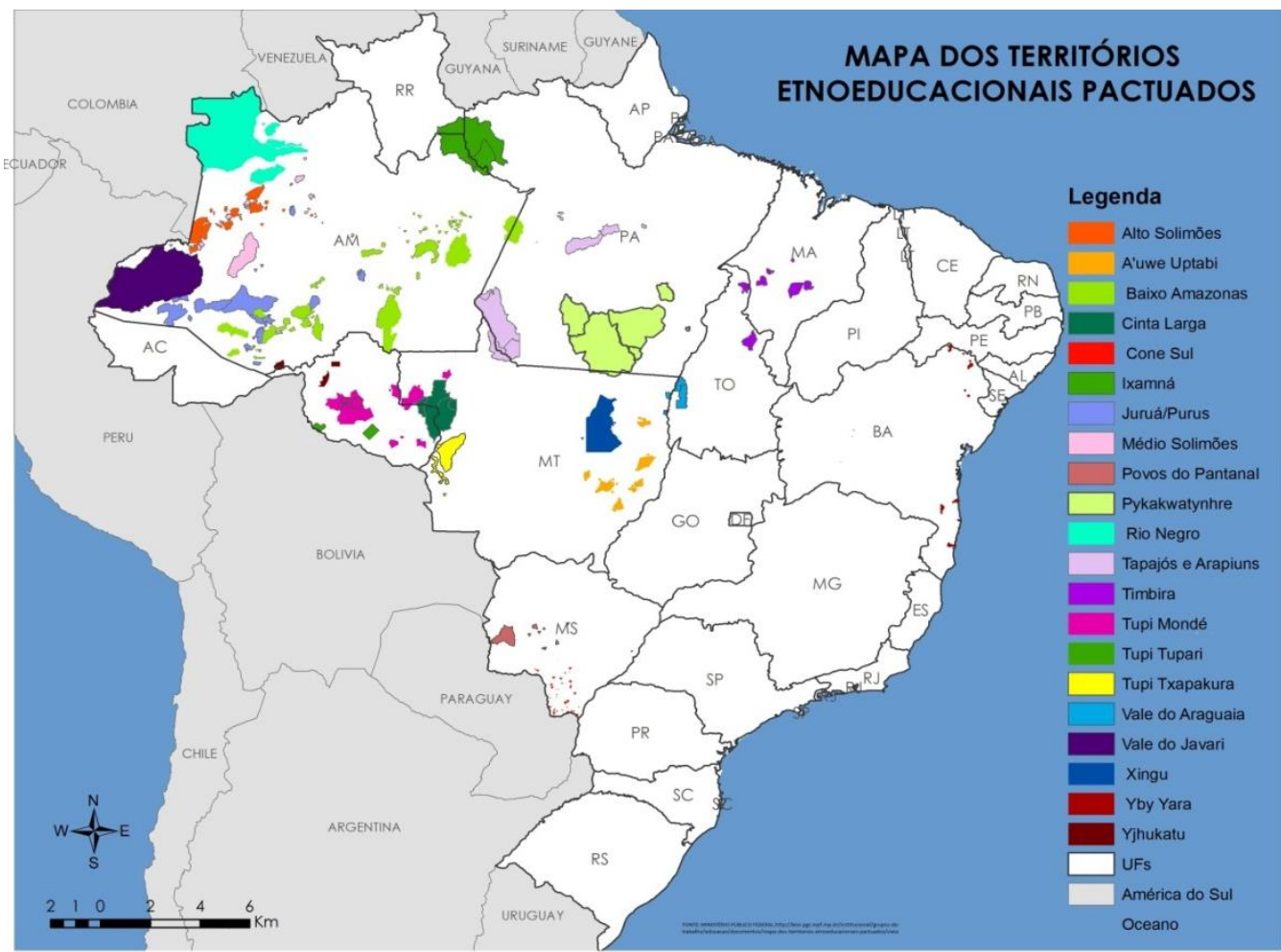

Do ponto de vista prático, os chamados TEE estão ainda em processo de formação. Foram pactuados até 2015 vinte e três (23) TEE, sendo catorze (14) até 2011. De acordo com Sousa (2013, p. 46/47), os primeiros 
TEE foram: Rio Negro, Baixo Amazonas, Jurua/Purus, Cone Sul, Povos do Pantanal, Xavante, Xingu, MédioSolimões, Yby Yara - Bahia, Mebengokre do Pará, Mapuera, Alto Solimões, Vale do Javari e Cinta-Larga. Em 2012, foram mais sete (07): Timbira, Vale do Araguaia, Tupi Mondé, Tupi Tupari, Txapakura, Ykukatu e Tapajós Arapiuns.

Em Mato Grosso do Sul, são dois Territórios Etnoeducacionais pactuados: Cone Sul e Povos do Pantanal. No TEE Cone Sul, estão em maioria absoluta os povos Kaiowá/Guarani/Nhãndeva (mas não apenas); há também significativa população Terena. Ainda que os TEE não sejam representados no limite dos municípios (assim como as terras indígenas também não o são), são dezoito (18) municípios dentro do TEE Cone Sul: Amambai, Antônio João, Aral Moreira, Bela Vista, Caarapó, Coronel Sapucaia, Dourados, Douradina, Eldorado, Japorã, Juti, Laguna Carapã, Maracaju, Paranhos, Ponta Porã, Rio Brilhante, Sete Quedas, Tacuru (Figura 03). Contudo, nem todos tem realizado ações para implementação do pacto estabelecido para e pelos povos indígenas, ainda que esteja previsto no marco legal.

Figura 3. Municípios do Território Etnoeducacional Cone Sul/MS

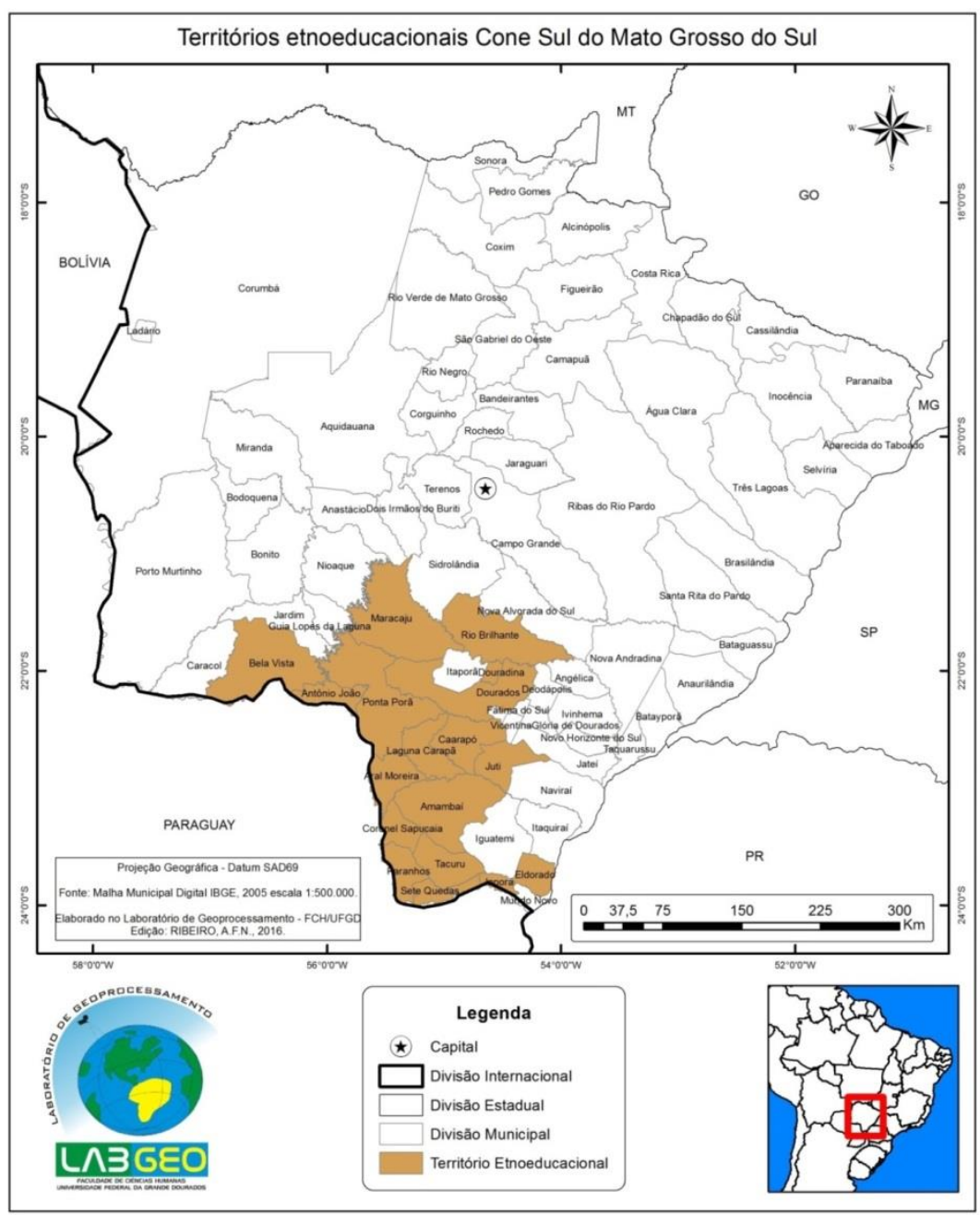


De acordo com o censo de 2010 (IBGE), o TEE Cone Sul conta com 528.701 habitantes, o que representa $21 \%$ da população do estado de Mato Grosso do Sul (2.449.024 habitantes). Em 2000, esse mesmo Instituto de pesquisa, apresentava uma contagem de 437.262 habitantes. (Tabela 01) Assim como a lógica nacional e estadual $^{11}$, a população concentra-se nas cidades.

Em 2000, a taxa média de população urbana nesses municípios já era de 79\%, mantendo-se em 79\%, em 2010; contudo, a predominância de residência urbana não é regra. O Municipio de Japorã, Laguna Carapã e Tacuru, apresentam situaçao inversa, em que, respectivamente, a população rural se sobrepõe significativamente a urbana: 6331/1400 habitantes (77\% rural); 3754/2737 habitantes (72\% rural); 6448/3767 habitantes (58\% rural). (Tabela 01)

Em números absolutos é possível observar o crescimento da população rural entre 2000 e 2010 , em todo o estado. Mas, verifica-se que houve uma tendência de aumento da população rural entre 2000 e 2010 , na maioria dos municípios do TEE Cone Sul, que cresceu no conjunto perto de $18 \%$ na década, com destaque para Japorã, Ponta Porã e Tacuru, contrariando a lógica de redução das últimas décadas do século XX. Apenas nos municípios de Eldorado e Sete Quedas há leve queda da população rural. Uma explicação para o crescimento da população rural, relaciona-se ao crescimento de assentamentos rurais, instalados no Sul de Mato Grosso do Sul e nesses municípios, bem como políticas do governo federal para geração de renda e permanência no campo. O padrão de crescimento urbano no Mato Grosso do Sul, motivado pela modernização da produção agropecuária e exôdo rural, gerou riqueza concentrada e pobreza, com conflitos e contradições explícitas no final do século XX.

Outro aspecto importante quanto à situação dos municípios é a sua população indígena. O IBGE (censo 2010) aponta que no Mato Grosso do Sul, das dez cidades com maiores proporções de população indígena, por situação de domicílio, sete estão no TEE Cone Sul. São elas: Japorã, Paranhos e Tacuru, respectivamente nas tres primeiras colocações, além de Amambai, Coronel Sapucaia, Caarapó e Douradina. (Tabela 02)

Tabela 1. Municipíos do TEE - Cone Sul/MS - Situação da População. Fonte http://www.atlasbrasil.org.br/2013

\begin{tabular}{|c|c|c|c|c|c|c|c|c|c|}
\hline & $\begin{array}{r}\text { População } \\
\text { total } \\
(1991) \\
\end{array}$ & $\begin{array}{r}\text { População } \\
\text { total } \\
(2000) \\
\end{array}$ & $\begin{array}{r}\text { População } \\
\text { total } \\
(2010) \\
\end{array}$ & $\begin{array}{r}\text { Populaçã } \\
\text { o rural } \\
(1991) \\
\end{array}$ & $\begin{array}{r}\text { Populaçã } \\
\text { o rural } \\
(2000) \\
\end{array}$ & $\begin{array}{r}\text { Populaçã } \\
\text { o rural } \\
(2010) \\
\end{array}$ & $\begin{array}{r}\text { População } \\
\text { urbana } \\
(1991) \\
\end{array}$ & $\begin{array}{r}\text { População } \\
\text { urbana } \\
(2000) \\
\end{array}$ & $\begin{array}{r}\text { População } \\
\text { urbana } \\
(2010) \\
\end{array}$ \\
\hline Brasil & 14682547 & 16979888 & 19075579 & 3583448 & 3184492 & 2983000 & 11099099 & 13795395 & 16092579 \\
\hline & 5 & 5 & 9 & 5 & 6 & 7 & 0 & 9 & 2 \\
\hline $\begin{array}{r}\text { Mato } \\
\text { Grosso } \\
\text { do Sul }\end{array}$ & 1780373 & 2078001 & 2449024 & 365926 & 330895 & 351786 & 1414447 & 1747106 & 2097238 \\
\hline Amambai & 25951 & 29484 & 34730 & 10672 & 10666 & 12355 & 15279 & 18818 & 22375 \\
\hline
\end{tabular}

11 No Mato Grosso do Sul, em 1970 a população urbana era de 38,8\%; em 1980, 57,5\%; em 1991, 79,4\% e em 2000, 84\%. Em 2010, $85,65 \%$ da população já era urbana no MS. 
Abreu

\begin{tabular}{|c|c|c|c|c|c|c|c|c|c|}
\hline $\begin{array}{l}\text { Antônio } \\
\text { João }\end{array}$ & 6636 & 7408 & 8208 & 1142 & 1111 & 1380 & 5494 & 6297 & 6828 \\
\hline $\begin{array}{r}\text { Aral } \\
\text { Moreira }\end{array}$ & 8064 & 8055 & 10251 & 5115 & 4784 & 4894 & 2949 & 3271 & 5357 \\
\hline Bela Vista & 19135 & 21764 & 23181 & 3014 & 3741 & 4254 & 16121 & 18023 & 18927 \\
\hline Caarapó & 22492 & 20706 & 25767 & 8227 & 6050 & 7458 & 14265 & 14656 & 18309 \\
\hline $\begin{array}{c}\text { Coronel } \\
\text { Sapucaia }\end{array}$ & 11609 & 12810 & 14064 & 5822 & 3338 & 3856 & 5787 & 9472 & 10208 \\
\hline $\begin{array}{r}\text { Douradin } \\
\mathrm{a}\end{array}$ & 4741 & 4732 & 5364 & 2254 & 2029 & 2078 & 2487 & 2703 & 3286 \\
\hline Dourados & 135984 & 164949 & 196035 & 13128 & 15021 & 15030 & 122856 & 149928 & 181005 \\
\hline Eldorado & 11025 & 11059 & 11694 & 3565 & 2741 & 2346 & 7460 & 8318 & 9348 \\
\hline Japorã & 4785 & 6140 & 7731 & 3604 & 4935 & 6331 & 1181 & 1205 & 1400 \\
\hline Juti & 5273 & 4981 & 5900 & 2199 & 1616 & 1975 & 3074 & 3365 & 3925 \\
\hline $\begin{array}{l}\text { Laguna } \\
\text { Carapã }\end{array}$ & 4592 & 5531 & 6491 & 3227 & 3331 & 3754 & 1365 & 2200 & 2737 \\
\hline Maracaju & 22999 & 26219 & 37405 & 5643 & 5029 & 5181 & 17356 & 21190 & 32224 \\
\hline Paranhos & 9481 & 10215 & 12350 & 3688 & 4420 & 6087 & 5793 & 5795 & 6263 \\
\hline $\begin{array}{l}\text { Ponta } \\
\text { Porã }\end{array}$ & 50950 & 60916 & 77872 & 5275 & 6533 & 15805 & 45675 & 54383 & 62067 \\
\hline $\begin{array}{r}\text { Rio } \\
\text { Brilhante }\end{array}$ & 15975 & 22640 & 30663 & 4309 & 5963 & 6106 & 11666 & 16677 & 24557 \\
\hline $\begin{array}{r}\text { Sete } \\
\text { Quedas }\end{array}$ & 14994 & 10936 & 10780 & 6462 & 1937 & 1806 & 8532 & 8999 & 8974 \\
\hline Tacuru & 7233 & 8717 & 10215 & 3895 & 4337 & 6448 & 3338 & 4380 & 3767 \\
\hline Total & 381919 & 437262 & 528701 & 91241 & 87582 & 107144 & 290678 & 349680 & 421557 \\
\hline
\end{tabular}

Os dados expressos na Tabela 02 demonstram a população indígena residente em terras indígenas (TI), não levando em consideração a população que vive fora das reservas e aldeias. É, portanto, uma aproximação, devendo ser relativizada. Nesse caso, foram utilizados os dados do IBGE (2010) e também do Ministério Público Federal (2016) para compor a população em municípios como Ponta Porã, que não estava contemplado nos dados do IBGE (censo 2010), mas também para qualificar a informação, inserindo informações do MPF relativo à Yvi Katu, em Japorã, não contemplado nos dados do censo de 2010.

Tabela 2. Municípíos do TEE - Cone Sul/MS População indígena relativa/Município. Org. ABREU (2017). Fonte: Dados do IBGE (censo 2010) e MPF (2016) (http://www.mpf.mp.br/ms/sala-de-imprensa/publicacoes/dia-do-indio-tekoha/tekoha-iii-tabela-de-povosindigenas)

\begin{tabular}{cccc}
\hline Municípios & População Indígena & População total & $\begin{array}{c}\text { População Indígena/ } \\
\text { População total ( \%) }\end{array}$ \\
\hline Amambai & 6882 & 34730 & $\mathbf{1 9 , 8}$ \\
Antonio João & 1067 & 8208 & 13 \\
Aral Moreira & 533 & 10251 & 5,2 \\
Bela vista & 473 & 23181 & 2 \\
Caarapó & 4882 & 25767 & $\mathbf{1 9}$ \\
Coronel Sapucaia & 2578 & 14064 & 18,3 \\
Douradina & 1101 & 5364 & $\mathbf{2 0 , 5}$ \\
Dourados & 11452 & 196035 & 5,9 \\
Eldorado & 544 & 11694 & 4,7 \\
Japorã** & 5644 & 7731 & 73
\end{tabular}




\begin{tabular}{cccc} 
Juti & 591 & 5900 & 10 \\
Laguna Carapã & 891 & 6491 & 13,7 \\
Maracaju & 224 & 37405 & 0,6 \\
Paranhos & 4378 & 12350 & $\mathbf{3 5 , 5}$ \\
Ponta Porã* & 1232 & 77872 & 1,6 \\
Sete Quedas & 284 & 10780 & 2,6 \\
Tacuru & 3695 & 10215 & $\mathbf{3 6 , 2}$ \\
\hline *Dados MPF. ** Dados compostos IBGE/MPF. ***
\end{tabular}

${ }^{*}$ Dados MPF. ${ }^{* *}$ Dados compostos IBGE/MPF. ${ }^{* * *}$

O estado de Mato Grosso do Sul apresenta, pelo censo 2010, 61.737 pessoas contabilizadas como residentes em Terras Indígenas. No TEE Cone Sul, contabilizamos 46.451 . Isso representa $75 \%$ de toda a população indígena do estado, residente no território, reconhecendo que é um dado relativo que pode ser um pouco menor ou até maior, pois não estão computados indígenas que vivem fora das TI reconhecidas e/ou regulamentadas. A representação média da população indígena do TEE, no conjunto da população geral do TEE Cone Sul, representa $8,7 \%$. Isso é significativo. Mas para alguns municípios a proporção é muito mais expressiva. Referimo-nos a Japorã, Tacuru, Paranhos, Amambai, Caarapó, Coronel Sapucaia e Douradina (Tabela 02). Os dados não falam por si, mas apurados com outros elementos e informações nos permite analisar o TEE Cone Sul e "suas gentes".

Veja-se a análise da situação da Mortalidade Infantil (TMI), por exemplo, que é ainda significativa na ampla maioria dos municípios do TEE Cone Sul, sobretudo quando comparada com o País e até com a população estadual (Tabela 03). Os dados de mortalidade infantil que eram elevados no País e nos municípios do TEE Cone Sul, na última década do século XX, sofreram queda significativa em 2010. A média nacional recuou de 44,68/1000, em 1991, para 16,7/1000 nascidos vivos. No caso do TEE Cone Sul, a média de 38,7/1000 é alta em 1991 e passou a 20/1000, em 2010. Há uma queda expressiva. Contudo, apesar disso, essa média é maior que a média nacional e que a estadual, que ficou em 18,14. (Tabela 03) Apenas Rio Brilhante e Maracaju tem TMI/média abaixo das médias nacional e estadual. Quando analisamos a TMI até 5 anos de idade, a média dos municípios do TEE Cone Sul fica ainda mais alta e distante da Nacional. Apenas os municípios de Dourados, Maracaju e Rio Brilhante não ultrapassam a média estadual em TMI.

Evidentemente, que a queda na mortalidade infantil no País e também nesses municípios encontra lastro em políticas públicas de controle de endemias e questões patológicas, que aconteceram, sobretudo, durante a primeira década do século XXI. No caso das comunidades indígenas, a atuação da Fundação Nacional de Saúde (FUNASA), desde 1999 e, posteriormente, a reestruturação a partir de 2010 (Decreto Presidencial 7336/2010), com a transferência da "saúde indígena" para a Secretaria Especial de Saúde Indígena/Ministério da Saúde (SESAI/MS), também foram mudanças importantes, pela possibilidade de tratamento diferenciado e específico.

Os dados da Fundação Nacional de Saúde, referentes ao ano de 2001 (MATO GROSSO DO SUL, 2002) são indicadores de que o coeficiente de mortalidade infantil nos seis polos do DSEI - Distrito Sanitário Especial 
Indígena-MS - no Sul de Mato Grosso do Sul, era de 74,01/1000 n.v. Nesse contexto, o caso dos municípios de Coronel Sapucaia, com 125/1000, seguido de perto por Antonio João, com um índice de 104/1000 são expressivos. No Brasil, os dados para mortalidade infantil indígena era em 2000, 74,6/1000 e no Mato Grosso do Sul, no mesmo ano, era 80,55/1000. De acordo com Ferreira (2010), nesta unidade da federação, a mortalidade infantil indígena, em 2001 era 65,7/1000 e em 2007, 42,3/1000.

Tabela 3. Municipíos do TEE - Cone Sul/MS - Mortalidade Infantil (MI). http://www.atlasbrasil.org.br/2013/pt/consulta

\begin{tabular}{|c|c|c|c|c|c|c|}
\hline & $\begin{array}{l}\text { Mortalidade } \\
\text { infantil } \\
(1991)\end{array}$ & $\begin{array}{l}\text { Mortalidade } \\
\text { infantil } \\
(2000)\end{array}$ & $\begin{array}{l}\text { Mortalidade } \\
\text { infantil } \\
(2010)\end{array}$ & $\begin{array}{l}\text { Mortalidade } \\
\text { até } 5 \text { anos } \\
\text { de idade } \\
(1991)\end{array}$ & $\begin{array}{l}\text { Mortalidade } \\
\text { até } 5 \text { anos } \\
\text { de idade } \\
(2000)\end{array}$ & $\begin{array}{l}\text { Mortalidade } \\
\text { até } 5 \text { anos } \\
\text { de idade } \\
\text { (2010) }\end{array}$ \\
\hline Brasil & 44,68 & 30,57 & 16,7 & 55,74 & 36,98 & 18,83 \\
\hline Mato Grosso do Sul & 34,73 & 25,53 & 18,14 & 40,72 & 29,94 & 21,47 \\
\hline Amambai & 32,89 & 22,73 & 19,4 & 38,58 & 26,66 & 23,37 \\
\hline Antônio João & 40,94 & 35,02 & 21,6 & 47,95 & 41,02 & 25,94 \\
\hline Aral Moreira & 31,59 & 26,51 & 21,7 & 37,07 & 31,11 & 26,05 \\
\hline Bela Vista & 34,1 & 26,2 & 18,1 & 39,99 & 30,73 & 21,78 \\
\hline Caarapó & 40,94 & 29,51 & 18,4 & 47,95 & 34,56 & 22,11 \\
\hline Coronel Sapucaia & 31,59 & 26,51 & 20,8 & 37,07 & 31,11 & 25,02 \\
\hline Douradina & 40,94 & 30,23 & 20,5 & 47,95 & 35,41 & 24,6 \\
\hline Dourados & 31,19 & 24,15 & 17 & 36,6 & 28,34 & 20,04 \\
\hline Eldorado & 44,78 & 26,2 & 18,8 & 52,42 & 30,67 & 22,54 \\
\hline Japorã & 52,95 & 38,44 & 22,6 & 61,89 & 44,93 & 27,15 \\
\hline Juti & 40,77 & 32,47 & 25,2 & 47,65 & 37,95 & 30,26 \\
\hline Laguna Carapã & 32,89 & 22,77 & 19 & 38,58 & 26,71 & 22,79 \\
\hline Maracaju & 31,41 & 18,92 & 13,9 & 36,85 & 22,2 & 16,78 \\
\hline Paranhos & 47,42 & 28,09 & 20,2 & 55,48 & 32,86 & 24,31 \\
\hline Ponta Porã & 29,64 & 21,69 & 20,1 & 34,78 & 25,45 & 24,13 \\
\hline Rio Brilhante & 40,63 & 21,99 & 15 & 47,6 & 25,76 & 18,04 \\
\hline Sete Quedas & 44,6 & 33,1 & 24,1 & 52,2 & 38,74 & 28,96 \\
\hline Tacuru & 47,42 & 33,1 & 23,7 & 55,48 & 38,73 & 28,45 \\
\hline Media & 38,70 & 27,64 & 20,0 & 45,33 & 32,38 & 24,01 \\
\hline
\end{tabular}

A questão a ser tratada, é que as altas taxas de mortalidade infantil no estado e, também, nos municípios que compõem a TEE Cone Sul, tem relação com a elevada taxa de mortalidade infantil indígena no DSEI-MS e nos polos, sobretudo porque a representação da população indígena é significativa, especialmente nos municípios do TEE Cone Sul. ${ }^{12}$

\footnotetext{
12 Em 2016, de acordo com dados publicados em Public.Tableau, os municípios em questão tiveram variações interessantes. Sendo que em nove deles (Aral Moreira, Bela Vista, Caarapó, Coronel Sapucaia, Dourados, Eldorado, Juti, Ponta Porã, Rio Brilhate) mantevese a queda na taxa de TMI. Contudo, em 8 houve reversão no movimento de queda, com aumento da TMI. Sendo que em alguns casos o aumento é significativo. Citamos especialmente Tacuru, com 38,89 TMI, em 2016; Japorã, com 36,36 de TMI, no mesmo ano. Evidentemente que os bancos de dados são diferentes, motivo pelo qual citamos em nota, aguardando que o IBGE, se manter a base de dados para 2020, possa atualizar, contudo, não interfere na nossa análise em que são os municípios com maior população indígena relativa é também aqueles que tem acumulado o maior numero de TMI. Ver base dos dados: 
Outro elemento que interessa sobremaneira é aquele relativo ao analfabetismo, que ainda permanece elevado na segunda década do século XXI, nos municípios do TEE Cone Sul (Tabela 04).

Os dados gerais dos municípios apresentam apenas Dourados, Maracaju e Rio Brilhante com taxas inferiores à estadual e à nacional. O município de Japorã é o que apresenta a maior taxa de analfabetismo, seguido de Paranhos, Sete Quedas, Coronel Sapucaia e Tacuru, todos acima de 20\%.

Quando analisamos as taxas específicas nas comunidades indígenas, em Terras Indígenas, verifica-se que os percentuais são muito mais elevados, com algumas situações que chamam a atenção.

No caso de Japorã, por exemplo, a taxa geral é maior do que a indígena, mas considerando a situação de relatividade dos dados indígenas, uma vez que o IBGE considera apenas aqueles residentes nas áreas indígenas $(\mathrm{TI})$ e, sobretudo, o impacto da população indígena na população total, é possível reconhecer a validade da informação. Paranhos, Tacuru e Douradina, municípios também com expressiva taxa de população indígena relativa, demonstram situação similar, com proximidade das taxas de analfabetismo da população geral e indígena.

Tabela 4. Municípios do TEE - Cone Sul/MS - Taxa de analfabetismo pessoas acima de 10 anos ou mais nos municípios e em Terras Indígenas (TI). Dados organizados por Abreu (2018). Fonte: http://www.atlasbrasil.org.br/2013/pt/consulta e IBGE indígenas (2010).

\begin{tabular}{ccc}
\hline Baxa de analfabetismo pessoas & $\begin{array}{c}\text { Taxil } \\
\text { acima de anos ou mais de } \\
\text { idade (2010) }\end{array}$ & $\begin{array}{c}\text { Taxa de analfabetismo pessoas } \\
\text { acima de 10 anos ou mais de } \\
\text { idade, residentes em TI }\end{array}$ \\
\hline Mato Grosso do Sul & 12,85 & 29,79 \\
Amambai & 9,22 & 18,81 \\
Antônio João & 13,39 & 23,48 \\
Aral Moreira & 14,64 & 27,5 \\
Bela Vista (MS) & 16,95 & 36,6 \\
Caarapó & 11,37 & 41,95 \\
Coronel Sapucaia & 13,79 & 18,58 \\
Douradina & 21,96 & 33,15 \\
Dourados & 11,42 & 12,39 \\
Eldorado & 6,94 & 16,08 \\
Japorã & 15,68 & 20,71 \\
Juti & 28,79 & 25,07 \\
Laguna Carapã & 20,4 & 30,38 \\
Maracaju & 14,54 & 31,05 \\
Paranhos & 8,58 & 19,73 \\
Ponta Porã* & 22,87 & 23,87 \\
Rio Brilhante* & 10,81 & \\
Sete Quedas & 9,14 & 22,15 \\
Tacuru & 22 & 22,15 \\
\hline
\end{tabular}

*Os dados de Ponta Porã e Rio Brilhante não foram computados pelo IBGE. 
Os dados de educação, aqui expressos pela taxa de analfabetismo, já foram muito piores e isso se expressa no IDHM dos municípios. De acordo com a Tabela 05, é possível aferir que a situação de IDHM, no Brasil e em cada município do TEE Cone Sul, cresceu significativamente, desde 1991, quando, dos 18 municípios, 10 não chegavam a 0,4, muito distantes do IDHM nacional, de 0,493. Em 2010, todos os municípios tiveram entre 1 e 1,5 de acréscimo em seu IDHM, o que é significativo. Mas, em alguns como Coronel Sapucaia, Japorã, Paranhos e Tacuru, ainda há significativa distância do IDHM nacional.

A melhoria do IDHM, sem dúvida, está relacionada ao IDHM Educação, que tem expressivo crescimento em nível nacional, mas é representativo nos municípios do TEE Cone Sul, com pelo menos oito municípios apresentando crescimento de 2 pontos ou mais em seu IDHM Educação. São eles: Aral Moreira, Bela Vista, Caarapó, Eldorado, Juti, Laguna Carapã, Maracaju e Paranhos.

Tabela 5. Municípíos do TEE - Cone Sul/MS - IDHM e Renda per capita. Fonte: http://www.atlasbrasil.org.br/2013/pt/consulta/

\begin{tabular}{|c|c|c|c|c|c|c|c|c|c|c|c|c|}
\hline & $\begin{array}{l}\text { IDHM } \\
\text { (1991) }\end{array}$ & $\begin{array}{l}\text { IDHM } \\
(2000)\end{array}$ & $\begin{array}{l}\text { IDHM } \\
(2010)\end{array}$ & $\begin{array}{l}\text { IDHM } \\
\text { Renda } \\
\text { (1991) }\end{array}$ & $\begin{array}{l}\text { IDHM } \\
\text { Renda } \\
\text { (2000) }\end{array}$ & $\begin{array}{l}\text { IDHM } \\
\text { Renda } \\
(2010)\end{array}$ & $\begin{array}{l}\text { IDHM } \\
\text { Educação } \\
(1991)\end{array}$ & $\begin{array}{l}\text { IDHM } \\
\text { Educação } \\
(2000)\end{array}$ & $\begin{array}{l}\text { IDHM } \\
\text { Educação } \\
(2010)\end{array}$ & $\begin{array}{l}\text { Renda } \\
\text { per } \\
\text { capita } \\
(1991) \\
\end{array}$ & $\begin{array}{l}\text { Renda } \\
\text { per } \\
\text { capita } \\
(2000) \\
\end{array}$ & $\begin{array}{l}\text { Renda } \\
\text { per } \\
\text { capita } \\
(2010) \\
\end{array}$ \\
\hline Brasil & 0,493 & 0,612 & 0,727 & 0,647 & 0,692 & 0,739 & 0,279 & 0,456 & 0,637 & 447,56 & 592,46 & 793,87 \\
\hline Amambai & 0,447 & 0,576 & 0,673 & 0,605 & 0,649 & 0,683 & 0,209 & 0,384 & 0,546 & 345,93 & 455,04 & 561,14 \\
\hline $\begin{array}{l}\text { Antônio } \\
\text { João }\end{array}$ & 0,373 & 0,509 & 0,643 & 0,534 & 0,553 & 0,633 & 0,146 & 0,342 & 0,526 & 221,28 & 249,89 & 411,49 \\
\hline $\begin{array}{l}\text { Aral } \\
\text { Moreira }\end{array}$ & 0,397 & 0,520 & 0,633 & 0,58 & 0,582 & 0,628 & 0,152 & 0,324 & 0,507 & 295,34 & 300,12 & 398,5 \\
\hline Bela Vista & 0,468 & 0,580 & 0,698 & 0,626 & 0,647 & 0,699 & 0,235 & 0,404 & 0,585 & 393,25 & 447,5 & 621,23 \\
\hline Caarapó & 0,422 & 0,548 & 0,692 & 0,592 & 0,603 & 0,676 & 0,191 & 0,376 & 0,592 & 317,58 & 341,75 & 537,01 \\
\hline $\begin{array}{l}\text { Coronel } \\
\text { Sapucaia }\end{array}$ & 0,337 & 0,488 & 0,589 & 0,545 & 0,585 & 0,607 & 0,099 & 0,267 & 0,417 & 237,27 & 305,67 & 350,37 \\
\hline Douradina & 0,442 & 0,567 & 0,699 & 0,598 & 0,622 & 0,706 & 0,218 & 0,406 & 0,597 & 331,07 & 384,47 & 648,98 \\
\hline Dourados & 0,512 & 0,636 & 0,747 & 0,645 & 0,698 & 0,753 & 0,292 & 0,487 & 0,657 & 442,68 & 615,48 & 866,4 \\
\hline Eldorado & 0,386 & 0,551 & 0,684 & 0,565 & 0,596 & 0,674 & 0,157 & 0,377 & 0,577 & 269,11 & 325,74 & 530,89 \\
\hline Japorã & 0,29 & 0,399 & 0,526 & 0,436 & 0,495 & 0,547 & 0,091 & 0,188 & 0,337 & 120,61 & 174,32 & 241,32 \\
\hline Juti & 0,353 & 0,48 & 0,623 & 0,511 & 0,577 & 0,646 & 0,128 & 0,269 & 0,485 & 191,76 & 289,72 & 446,17 \\
\hline $\begin{array}{l}\text { Laguna } \\
\text { Carapã }\end{array}$ & 0,363 & 0,535 & 0,672 & 0,568 & 0,651 & 0,676 & 0,12 & 0,307 & 0,545 & 273,85 & 460,23 & 536,02 \\
\hline Maracaju & 0,48 & 0,597 & 0,736 & 0,641 & 0,66 & 0,744 & 0,243 & 0,408 & 0,613 & 432,85 & 487,24 & 819,6 \\
\hline Paranhos & 0,336 & 0,441 & 0,588 & 0,523 & 0,544 & 0,566 & 0,114 & 0,214 & 0,444 & 207,7 & 235,81 & 271,52 \\
\hline $\begin{array}{l}\text { Ponta } \\
\text { Porã }\end{array}$ & 0,495 & 0,6 & 0,701 & 0,662 & 0,67 & 0,708 & 0,254 & 0,416 & 0,598 & 493,02 & 516,27 & 653,36 \\
\hline $\begin{array}{l}\text { Rio } \\
\text { Brilhante }\end{array}$ & 0,475 & 0,584 & 0,715 & 0,654 & 0,658 & 0,72 & 0,246 & 0,393 & 0,59 & 468,37 & 479,27 & 705,6 \\
\hline $\begin{array}{l}\text { Sete } \\
\text { Quedas }\end{array}$ & 0,393 & 0,512 & 0,614 & 0,573 & 0,653 & 0,66 & 0,164 & 0,291 & 0,45 & 283,15 & 464,98 & 487 \\
\hline Tacuru & 0,343 & 0,469 & 0,593 & 0,541 & 0,544 & 0,615 & 0,117 & 0,267 & 0,434 & 231,57 & 236,7 & 367,68 \\
\hline
\end{tabular}

A variação positiva em todos os municípios está relacionada com políticas educacionais e sociais, que levaram a ampliação de vagas; a melhoria nas condições e infraestrutura das escolas; a inclusão social de segmentos da população, como os indígenas, em todos os niveis de escolarização; acesso aos diferentes níveis de formação, inclusive, nível superior; apoio a permanência na escola e no ensino superior e formação de professores indígenas, desde o final do século XX. 
O movimento de implantação das escolas indígenas (ou instalação de escolas municipais em aldeias e reservas) e a criação dos cursos de formação de professores índígenas, em nível médio e também em nível superior, tem impacto importante nos dados. Da mesma forma, as escolas em assentamentos e a formação de professores específicos para educação do campo, são importantes para melhoria das condições do IDHM nos municípios do TEE Cone Sul.

Contudo, apesar de melhoria dos índices evidenciadas, a Tabela 05 indica também que a renda per capita na maioria desses municípios está muito aquém da renda Nacional, com exceção para os municípios de Dourados e Maracaju, que apresentam dados acima da renda per capita nacional. Os municípios de Japorã e Paranhos, que tem as maiores taxas de população indígena relativa, têm as menores rendas per capita (menor que 0,3), enquanto Tacuru, Coronel Sapucaia e Aral Moreira, não chegam a 0,4.

Trata-se, o Territorio Etnoeducacional Cone Sul, de uma espacialidade formada por desigualdade e concentração, com índices elevados de mortalidade infantil, baixo indíce de escolaridade, analfabetismo e baixa renda agregada, condição que se agrava para as comunidades indígenas, sujeitas a condições de ainda mais desigualdade e dependência de investimentos públicos e sociais.

TEE Cone Sul: sem diálogo ... conflitos ... algumas considerações para finalizar!

O esboço aqui realizado, ainda que parcial, reflete condições consolidadas pelo processo de integração do território nacional ao modelo de produção capitaneado pela agroindustrialização, que se mostrou excludente e fomentou a pobreza como uma condição que atinge aos indígenas fundamentalmente, mas não apenas.

Assim, a consolidação do território etnoeducacional comparece como uma potencialidade, bem como o Programa Nacional dos Territórios Etnoeducacionais ${ }^{13}$ (PNTEE), que entre outras coisas, visa ampliar e qualificar as formas de acesso dos índios à educação básica e superior, como condição de autonomia historicamente reivindicada. De acordo com Rossato e Vinha (2017, p.14):

Este desejo foi verbalizado pelo professor Guarani Valentim Pires, em 1995: Queremos, com a ajuda da escola, com uma educação que responda às nossas necessidades, conquistar a autonomia socieconcomica e cultural e sermos reconhecidos como cidadãos etnicamente diferentes. Neste processo, a escola tem um papel fundamental. Não queremos mais que a escola sirva para desestruturar nossa cultura e nosso jeito de viver, que não passe mais para nossas crianças a ideia de que somos inferiores e que, por isso, precisamos seguir o modelo dos brancos para sermos respeitados. Pelo contrário, achamos que temos muito para ensinar do nosso jeito de viver para os brancos, e queremos o respeito da sociedade que se diz democrática, e do governo que deve cumprir a lei que ele mesmo criou.

13 Ver Portaria 1062 de 30/10/2013.

http://pesquisa.in.gov.br/imprensa/isp/visualiza/index.jsp?data=31/10/2013\&jornal=1\&pagina=44\&totalArquivos=120 
Os investimentos planejados para atendimento de reformas e construções de escolas, criação de cursos superiores, auxílio aos estudantes indígenas, devem ser acessados por índios e gestores das escolas existentes e novas e serem fomentados no interior dos TEE. O PNTEE foi criado em 2013, como política governamental, mas frente ao processo de ruptura político-institucional, advindo com o Golpe de 2016, não tem qualquer garantia de permanência, nesse final da segunda década do século XXI, em que toda a política associada aos governos do presidente Luis Inácio Lula da Silva e também da presidenta Dilma Roussef estão em questionamento e/ou combate.

De toda forma, os governos e entes governamentais dos municípios, estados e órgãos públicos (como universidades públicas, secretarias municipais e estaduais de educação, Embrapa, por exemplo) ficaram ainda convocados e em tese obrigados a assumirem responsabilidades frente à educação escolar indígena. Segundo Sousa (2013), contudo, a indiferença dos entes da administração pública é uma dificuldade para a realização dos TEE e, sobretudo, para implementação da própria Carta Magma.

Em Carta Aberta da Comissão Nacional de Educação Escolar Indígena "sobre a implementação dos Territórios Etnoeducacionais", em 27 e 28 de maio de 2014, a avaliação é expressiva das demandas ainda por solucionar:

\begin{abstract}
Avaliando que: Os TEEs não se tornaram unidades executoras, mantendo as deficiências de implementação e baixa execução das ações do PAR destinadas às comunidades indígenas; O MEC não se estruturou administrativamente para exercer o papel de coordenador dos TEEs tal como dispõe o Decreto 6.861/2009, não contando com equipe técnica suficiente para os desafios colocados pela nova política que prevê ações de planejamento, acompanhamento e avaliação dos territórios; A contratação de consultores não é a resposta administrativa adequada para a implantação e implementação dos TEEs, uma vez que estes não podem dar respostas institucionais aos problemas verificados; Há dificuldades e morosidade no processo de operacionalização do decreto 6.861 com vários territórios ainda não definidos ou pactuados, inexistindo agenda para conclusão da implementação do decreto em todo o país; Não há informações disponibilizadas qualitativas e quantitativas sobre o funcionamento dos TEEs pactuados, seus êxitos e dificuldades. $O$ instrumento de pactuação dos territórios não garante o compromisso dos gestores federais, estaduais e municipais, que continuam a atuar de forma desarticulada, gerando ações desencontradas e desconexas no mesmo território.
\end{abstract}

Em pesquisa recente, em conjunto com pesquisadoras da UFGD, da UNICAMP e da Universidade Católica Dom Bosco ${ }^{14}$ (projeto denominado "Educação Escolar Indígena no Etnoterritório do Cone Sul: a percepção dos gestores institucionais") realizamos um diagnóstico da situação do TEE Cone Sul, considerando o conhecimento, perspectivas e envolvimento dos gestores municipais sobre a existência e encaminhamentos do TEE, em cada município envolvido. Outra perspectiva da pesquisa era orientar os gestores para a implementação do etnoterritório ${ }^{15}$ (TEE) Cone Sul.

\footnotetext{
14 Projeto de Pesquisa aprovado pela FUNDECT (EDUCA MS 13/2014, sob coordenação da professora Marina Vinha, da UFGD.

${ }^{15}$ Sobre etnoterritório ver: BARABAS (2004) disponível em:

http://desacatos.ciesas.edu.mx/index.php/Desacatos/article/view/1091/939
} 
Há que se reconhecer a dificuldade dessa condição, sobretudo nos municípios, cujas alternâncias de governos e também as relações próximas com as comunidades indígenas são sempre difíceis, interferindo na implementação das políticas. O resultado deste projeto foi publicado como livreto, elaborado pelo conjunto das pesquisadoras, apresentando resultados, discussões e orientações para os gestores ou para quem dele quiser fazer uso. ${ }^{16}$ Além disso, realizamos uma oficina com os gestores dos municípios envolvidos, visando justamente realizar o diagnóstico, mas, sobretudo, fomentar o interesse, tirar diretrizes, informar e ajudar na implementação da pactuação do TEE Cone Sul pelos órgãos públicos e executivo de cada município. Contudo, a participação na atividade foi pequena. Dos dezoito (18) municípios envolvidos com o pacto do TEE, com diferentes justificativas e até negligência ao convite, compareceram representantes de apenas seis municípios: Tacuru, Sete Quedas, Ponta Porã, Maracaju, Eldorado e Caarapó. Mesmo assim, dos representantes que participaram, a maioria não tinha informações sobre os TEE, seu significado e as responsabilidades do município, ou mesmo das gestões escolares.

Além disso, quando se fala em educação diferenciada indígena não se está falando de unidade e isso decorre de muitas questões que são de ordem diversa: edificações, gestão e conhecimento, professores, comunidade indígena que frequenta a escola e a situação/localização das escolas. Existem escolas que são rurais atendendo estudantes indígenas. Tem áreas indígenas que não tem escolas e os estudantes dependem de transporte (quase sempre em condições precárias) para estudar. Existem escolas em que participam alunos de diferentes etnias; escolas em que os professores são indígenas e outras em que os professores são não Índios. Sem dizer, que em áreas de retomada, como há conflitos, os diálogos entre os governos e indígenas são limitadores e a população indígena em idade escolar acaba desassistida pela administração pública, em diferentes níveis, com amplo respaldo da opinião pública.

Foi possível observar também, que existem áreas em que há condições melhores em termos de organização escolar, com gestores conhecedores e até estudiosos da causa, com escolas indígenas instaladas e em condições de implantação do TEE e as vantagens e recursos que poderiam demandar deste Programa governamental, mediante o Pacto assinado em 2009, quando da criação dos TEE.

Além do pacto, foi também elaborado o Plano dos $\mathrm{TEE}^{17}$, em 2009. Entre ações definidas para cumprimento das secretarias municipais de educação está:" Manter o pleno funcionamento das Escolas Municipais Indígenas de Ensino Fundamental com filosofia de educação diferenciada."18

\footnotetext{
16 Organizado por Marina Vinha, em coautoria com as pesquisadoras e coautoras Maria Beatriz Rocha Ferreira; Marina Vinha, Noemia dos Santos Pereira Moura, Silvana de Abreu, Vera Regina Toledo Rossato, Veronice Lovato Rossato. Ver VINHA (2016). 17 Plano dos TEE elaborado em 2009, durante a I Conferencia Regional de Edcuação Escolar Indígena de Dourados-MS. Por meio dele ficou firmado os compromissos de cada ente que participa do TEE.

18 Ver: Vinha (2017, p.31)
} 
Ao que se pode observar, há um conjunto de demandas que foram encaminhadas via legislação e normas, mas têm passado ao largo, em franco descumprimento legal, constituindo-se ainda em normas de gaveta. ${ }^{19}$ Há críticas aos governos que se sucederam desde a Constituição de 1988 , sobretudo quanto à agilidade no andamento das demarcações, mas após o Golpe de 2016, no Governo Michel Temer ficou evidenciado a consolidação de um pacto político envolvendo a bancada ruralista e os interesses que levaram ao afastamento da Presidenta Dilma Roussef. Assim apontou Buzatto (2017, p.15):

\begin{abstract}
Com Temer no comando do Executivo federal, os agressores se sentiram mais seguros para cometer seus crimes tanto contra os indivíduos como contra o patrimônio dos povos indígenas. A invasão e o esbulho possessório alastraram-se como pólvora sobre os territórios indígenas e ameaçam a sobrevivência de muitos povos, inclusive de grupos isolados. Denúncias foram apresentadas às autoridades federais, que têm se omitido recorrentemente de suas responsabilidades acerca do tema. O estrangulamento financeiro e a instrumentalização política da Funai por forças reacionárias do militarismo, do integracionismo, do fundamentalismo religioso cristão e do ruralismo também se aprofundaram em 2017. Além de inviabilizar o cumprimento das atribuições institucionais e constitucionais de demarcação e proteção das terras indígenas, o fechamento de bases de proteção a povos livres (isolados) na Amazônia tem o escopo de reabrir os tempos sombrios de eliminação de povos inteiros. Massacres foram noticiados, mas nunca confirmados ou desmentidos pelo governo brasileiro. Além disso, o órgão indigenista passou a servir como plataforma para práticas persecutórias contra povos indígenas e organizações de apoio.
\end{abstract}

O texto faz parte do "Relatório da Violência contra os Povos Indígenas no Brasil" - Dados de 2017 - e explicita a trama organizada no governo pós-golpe visando submeter povos indígenas a perda do direito a terra, com base no marco temporal. De acordo com Rangel e Liebigott $(2017$, p.16):

O governo Temer impôs, no âmbito da administração pública federal, o Parecer 001/2017 da AdvocaciaGeral da União (AGU). Dentre outras anomalias jurídicas, este parecer pretende estender as 19 condicionantes do caso da Terra Indígena Raposa Serra do Sol (Petição 3338), as teses do Marco Temporal da Constituição Federal de 1988 e o renitente esbulho no âmbito dos procedimentos de demarcação de todas as terras indígenas. Com este parecer, a AGU, a quem compete defender a União e todos os seus bens, legisla em defesa dos interesses privados e dos setores anti-indígenas e em detrimento dos interesses da União, já que é responsabilidade da União proceder a demarcação das terras indígenas, que passam a compor o seu patrimônio.

A despeito da questão do marco temporal há algo que fica explicitado, qual seja, que a possibilidade de reversão de áreas e a não demarcação tem estimulado o aumento dos conflitos, sobretudo com ataques de responsabilidade de fazendeiros em áreas de conflitos, indo na contramão da pactuação dos TEE.

\footnotetext{
${ }^{19}$ São normas recentes e que impactam nos TEE e na educação diferenciada indígena: Resolução N. 03, de 10 de novembro de 1999 : Fixa Diretrizes Nacionais para o funcionamento das escolas indígenas e dá outras providências; Deliberação do CEE/MS N. 6.767, de 25 de outubro de 2002: Fixa normas para organização, estrutura e funcionamento das Escolas Indígenas pertencentes ao Sistema Estadual de Ensino de Mato Grosso do Sul para a oferta da Educação Escolar Indígena e dá outras providências; Decreto № 6.861, de 27 de maio de 2009: Dispõe sobre a Educação Escolar Indígena, define sua organização em territórios etnoeducacionais, e dá outras providências; Resolução no 5, de 17 de dezembro de 2009: Fixa as Diretrizes Curriculares Nacionais para a Educação Infantil e também dá orientações curriculares para Educação Infantil em comunidades indígenas; Resolução N. 05, de 22 de junho de 2012. Define Diretrizes Curriculares Nacionais para a Educação Escolar Indígena na Educação Básica; Resolução/SED N. 2.600, de 04 de dezembro de 2012: Dispõe sobre a organização curricular e o regime escolar do ensino fundamental e do ensino médio, nas unidades escolares da Rede Estadual de Ensino, e dá outras providências; Resolução/SED N. 2.961, de 27 de abril de 2015 - CONE SUL: define Diretrizes para a Educação Escolar Indígena no Território Etnoeducacional Cone Sul; Deliberação CEE/MS N. 10.647, de 28 de abril de 2015: Fixa normas para a oferta da Educação Escolar Indígena no Sistema Estadual de Ensino de Mato Grosso do Sul e dá outras providências; entre outras..
} 
Segundo a Comissão Pastoral da Terra (CPT) da Conferência Nacional dos Bispos do Brasil (CNBB), ocorreram 1079 conflitos por terra em 2016, um número recorde desde o início da série estatística em 1985. (...) O número de assassinatos que diminuiu entre 2004 e 2014, se recuperou: 61 pessoas foram assassinadas em 2016 e, de janeiro a maio de 2017, 37 assassinatos rurais já foram registrados. Ao longo de 35 dias, de 20 de abril de 2017 a 24 de maio de 2017, ocorreram três ataques, com um total de 22 mortes. (CUNHA, 2017, s/p)

A eleição e posse do Governo Jair Bolsonaro (2019-2022), também trouxe dimensões agravantes para os povos indígenas e para a consolidação do etnoterritório, sobretudo com as mudanças propostas e impressas pelo novo governo, que já chegou retirando a Funai do Ministério da Justiça, transferindo o órgão para um "mix" chamado Ministério Mulher, da Família e dos Direitos Humanos, comandado por Damares Alves. A reforma também retirou da FUNAI a responsabilidade de demarcar terras indígenas, que foi transferida para o Ministério da Agricultura, para ser comandada pela deputada eleita pelo Mato Grosso do Sul, Tereza Cristina Correa da Costa Dias, que carrega a condição de ser ex-presidente da bancada ruralista na Câmara.

Em análise por uma comissão mista do Congresso Nacional, criada para avaliar a reforma administrativa do Governo Bolsonaro, realizada via medida provisória, a Comissão decidiu alterar diversos pontos da organização proposta pelo governo federal, entre os quais o funcionamento e as atribuições da FUNAl, devolvendo a questão da demarcação a FUNAl, bem como o órgão ao Ministério da Justiça. O Governo Bolsonaro explicita desde a campanha eleitoral o desejo em modificar o uso da terra indígena, visando incorporar as terras indígenas a produção comercial, possivelmente via arrendamentos e determinação em não mais promover demarcação. Condição que já era ventilada pelas medidas tomadas pelo governo Temer. No dia 19/06/2019, o Governo Bolsonaro insiste, por meio de outra Medida Provisória (MP 886/2019), em manter no Ministério da Agricultura, a questão da demarcação de terras indígenas, obrigando o Congresso a mais uma vez analisar o tema, além de declarar guerra, literalmente, aos povos indígenas. Em O Globo.com, o Jornal Nacional deu ênfase a fala do presidente Jair Bolsonaro:

\begin{abstract}
No interior de São Paulo, o presidente Bolsonaro voltou a dizer que a intenção dele é não demarcar nenhuma nova terra indígena. É uma pressão externa, a pressão de ONGs de fora do Brasil. Só tem reserva indígena praticamente em área rica. Nós queremos é integrar o índio à sociedade, o índio é um ser igual a eu e você. Quando ele se apresenta a nós, ele quer televisão, quer internet, quer futebol, quer ir ao cinema. Ele quer fazer o que nós fazemos; quer ir ao médico, quer ir ao dentista. É isso que nós queremos para o índio, integrar à sociedade como um ser humano igual a nós", declarou o presidente..$^{20}$
\end{abstract}

No Senado Notícias, a notícia evidencia a tomada de posição do governo em devolver o problema já analisado e talvez reverter a posição anterior. Há que se questionar essa prática, no mínimo inusitada, mas

\footnotetext{
20 Dísponível em: https://g1.globo.com/jornal-nacional/noticia/2019/06/19/bolsonaro-devolve-demarcacao-de-terras-indigenaspara-agricultura1.ghtml (acessado 20/06,/2019)
} 
também preocupante, sobretudo porque nas relações entre executivo e legislativo, muitas vezes o que prevalece são interesses pessoais e eleitoreiros. Diz a publicação:

A Medida Provisória 886/2019, editada nesta quarta-feira (19) pelo presidente Jair Bolsonaro, transfere a identificação e demarcação de terras indígenas para a alçada do Ministério da Agricultura. A MP, que muda ainda as atribuições de outras estruturas do governo federal, reverte decisão do Congresso Nacional, que subordinou a demarcação ao Ministério da Justiça. (...)

A MP 886 retorna agora a demarcação ao ministério comandado pela ministra (e deputada licenciada) Tereza Cristina, forçando o Congresso a rediscutir sobre a que pasta cabe essa competência. A medida provisória manteve na Justiça os assuntos relacionados aos direitos dos índios, com exceção da questão fundiária. ${ }^{21}$

Nesse contexto controverso, a questão dos territórios etnoeducacionais que sempre tiveram dificuldades na implantação, após 2016 tem estado absolutamente adormecida, do ponto de vista das ações governamentais. No Mato Grosso do Sul, cuja classe hegemônica conseguiu emplacar dois ministros para o governo Jair Bolsonaro, entre eles a ministra da agricultura, liderança do agronegócio; sem dúvida a indicação da demarcação para essa Pasta contraria os interesses de demarcação indígenas e é antiética, sobretudo porque a ministra vai definir sobre "seus" próprios interesses econômicos.

Até agora, o território etnoeducacional tem se consolidado como territorialidades; relações que acontecem por meio das escolas indígenas; do prestígio que professores indígenas incorporam e que consolida lideranças (outras); das lutas coletivas que as práticas e participações em diferentes fóruns, vêm ajudando a fomentar; nos cursos de formação, em nível básico e superior, sobretudo de professores índios, que podem retornar e reforçar os ideais culturais, além de formar conhecimentos e sujeitos índios em essência. O etnoterritório é assim, menos chão, para ser fundamentalmente "sentido", "essência", " sentimento", para quem dele participa ou busca construir. No dizer de Santos (2018, p.49):

Território é, por definição, a categoria da ordem e, portanto, não é uma identidade do objeto, mas uma condição da construção do conhecimento pelo sujeito - trata-se do sensório pensado ou o "concreto em pensamento". Assim, território não é algo em si e para si sem que seja, igualmente, a ordem como se realiza a construção do "saber do sujeito". Todo território possui sua paisagem e, portanto, estamos frente à relação entre aparência e essência, entre forma e conteúdo, entre o que percebo e o significado que construo a partir do percebido, entre o imediato e o mediatizado, entre o sentir e a cultura ou, enfim, frente ao processo mesmo de hominização do homem. (SANTOS, D: 2018, p. 49)

Concordamos com o autor na medida em que o território existe a partir dos sujeitos. Pode-se perceber o limiar entre o que pode ser mediatizado a partir da percepção dos sujeitos e aquilo que realmente acontece em dada escala temporal. No caso do etnoterritório impresso na política governamental que criou os TEE, sua dinâmica e a identidade buscada e consolidada efetivamente em ações do Estado instituído, se realiza por meio da educação formalizada e ofertada pelos poderes municipais e estaduais e suas ações ou não-ações (ou reações), sob os marcos de uma pactuação consolidada entre os Governos, a Funai e as comunidades indígenas

\footnotetext{
21 Disponível em: https://www12.senado.leg.br/noticias/materias/2019/06/19/mp-volta-a-transferir-demarcacao-de-terrasindigenas-para-o-ministerio-da-agricultura (acessado 20/06,/2019)
} 
de todo o país. Nesse sentido, há que se reconhecer que não há território etnoeducacional dos Povos Cone Sul acabado, mas o que há é um movimento em construção.

Se o etnoterritório seria a mediação dos sujeitos entre as escalas geográfico- histórica, que incorpora as relações políticas, a cultura, o social, soma-se a isso as significações e ressignificações possíveis de serem (des)construídas e novamente reconstruídas territorialidades G/K. Nesse sentido, mesmo que se tenha ampliadas as dificuldades no contexto do governo federal (desde 2016 e 2019-2022), tais condições, que necessitam ser superadas, tem força de resistência e o território etnoeducacional dos Povos Cone Sul, como utopia, é desejo de alcançar os diferentes e novos modus vivendus, o que colabora para a formação de sujeitos índios e inclusive não índios.

Assim, é preciso superar preconceitos e garantir a afirmação da diversidade em bases que avancem na simplória oposição atrasado/avançado; há que se lutar pela demarcação e posse da terra indígena, como essência para garantia de reprodução da existência desses povos; há que se lutar pelo direito à interculturalidade, que passa pela educação e se coloca como território etnoeducacional (TEE) e não aceita a “integração subordinada” apresentada no novo/velho discurso governamental. Resistência!

\section{REFERÊNCIAS}

AGUILERA URQUIZA, A. H. e NASCIMENTO, A. C. "O DESAFIO DA INTERCULTURALIDADE NA FORMAÇÃO DE PROFESSORES INDÍGENAS". In: Espaço Ameríndio, Porto Alegre, v. 4, n. 1, p. 44-60, jan./jun. 2010.

BACKES, J. L "A escola indígena intercultural: espaço/tempo de afirmação da identidade étnica e de desconstrução da matriz colonial”. In: INTERAÇÕES, Campo Grande, v. 15, n. 1, p. 13-19, jan./jun. 2014.

BALDI, C. A. Proteção Constitucional. Questão indígena tem de abandonar concepções racistas. Revista Consultor Jurídico, 2 de junho de 2008. Disponível em: http://www.mpf.mp.br/atuacao-tematica/ccr6/documentos-epublicacoes/artigos/docs/artigos/docs_artigos/artigo_protecao_constitucional.pdf

BARABAS, A.M. La construcción de etnoterritorios en las culturas indígenas de Oaxaca. In: Desacatos, núm.14, primavera-verano 2004, pp. 145-168. Disponível em: http://desacatos.ciesas.edu.mx/index.php/Desacatos/article/view/1091/939 (acessado em 03/05/2019)

BRASIL. Constituição da República Federativa do Brasil : texto constitucional promulgado em 5 de outubro de 1988, com as alterações determinadas pelas Emendas Constitucionais de Revisão nos 1 a 6/94, pelas Emendas Constitucionais nos 1/92 a 91/2016 e pelo Decreto Legislativo no 186/2008. - Brasília : Senado Federal, Coordenação de Edições Técnicas, 2016. 496 p. Disponível em: https://www2.senado.leg.br/bdsf/bitstream/handle/id/518231/CF88 Livro EC91 2016.pdf

BRASIL. Decreto № 5051, de 19/04/2004. Promulga a Convenção no 169 da Organização Internacional do Trabalho - OIT sobre Povos Indígenas e Tribais. Disponível em : http://www.planalto.gov.br/ccivil_03/_ato2004-2006/2004/decreto/d5051.htm

BRASIL. Decreto № 6.861 de 27/05/2009. Dispõe sobre Educação Escolar Indígena, define sua organização em territórios etnoeducacionais, e dá outras providências. Disponível em:

http://legislacao.planalto.gov.br/legisla/legislacao.nsf/Viw Identificacao/DEC\%206.861-2009?OpenDocument ou http://www.planalto.gov.br/ccivil_03/_Ato2007-2010/2009/Decreto/D6861.htm

BUZATTO, C. C Um país na mão de violentos. In: CIMI, Relatorio de Violencia contra os povos indigenas dados 2017. Disponível em: http://www.mpf.mp.br/atuacao-tematica/ccr6/documentos-e-publicacoes/publicacoes/mapa-da-violencia-contra-os-povosindigenas/Relatorioviolenciacontrapovosindigenas 2017Cimi.pdf 
COMISSÃO NACIONAL DE EDUCAÇÃO INDÍGENA SOBRE A IMPLEMENTAÇÃO DOS TERRITÓRIOS ETNOEDUCACIONAIS. CARTA ABERTA. Brasília/DF. Maio, 2014. Disponível em:

http://www.anped.org.br/sites/default/files/resources/Carta Aberta da Cneei sobre a implementac a o dos TEE.pdf

CUNHA, M. C. Povos indígenas cercados pela crise política do Brasil. In: Crisálida, Unicamp, 2017. Publicado em 09/08/2017. Disponível em: https://translate.google.com.br/translate?hl=pt-BR\&sl=en\&u=http://crisalida.eco.br/indigenous-peoples-boxed-inby-brazils-political-crisis/\&prev=search

FERREIRA, M. E. V. Aspectos demográficos e mortalidade de populações indígenas do Estado do Mato Grosso do Sul, Londrina-PR, 2010. (dissertação de mestrado)

FUNAI. Política Indigenista. http://www.funai.gov.br/index.php/nossas-acoes/politica-indigenista?start=13

FUNAI. O Brasil indígena (IBGE). http://www.funai.gov.br/index.php/indios-no-brasil/o-brasil-indigena-ibge

FUNAI. Modalidades de Terras Indígenas. http://www.funai.gov.br/index.php/indios-no-brasil/terras-indigenas

FUNAI. Demarcação de Terras. http://www.funai.gov.br/index.php/nossas-acoes/demarcacao-de-terras-indigenas?start=1

IBGE - Censo de 2010. http://www.ibge.gov.br

LACOSTE, Y. A geografia, isso serve antes de mais nada para fazer a guerra. São Paulo. Papirus, 1988. 1ạ ed.

MINISTÉRIO PÚBLICO FEDERAL. Tabela - Territórios Indígenas em MS. http://www.mpf.mp.br/ms/sala-deimprensa/publicacoes/dia-do-indio-tekoha/tekoha-iii-tabela-de-povos-indigenas

MINISTÉRIO PÚBLICO FEDERAL Mapa dos Territórios Etnoeducacionais Pactuados. Disponível em: http://www.mpf.mp.br/atuacaotematica/ccr6/dados-da-atuacao/grupos-de-trabalho/gt-educacao/docs/documentos/mapa-dos-territorios-etnoeducacionaispactuados/view

MOTA, J. G. B.. Territórios e territorialidades Guarani e Kaiowá: da territorialização precária na reserva indígena de Dourados à multiterritorialidade. UFGD, Dourados, 2011. (dissertação mestrado)

NAÇÕES UNIDAS PARA O DESENVOLVIMENTO, INSTITUTO DE PESQUISA ECONÔMICA APLICADA, FUNDAÇÃO JOÃO PINHEIRO - FJP. Atlas do Desenvolvimento Humano no Brasil. Disponível em: http://www.atlasbrasil.org.br/2013

RANGEL, L, H e LIEBIGOTT, R.A. O governo Temer legitimou a violência contra os povos indígenas. In: CIMI, Relatório de Violência contra os povos indígenas dados 2017. Disponível em: http://www.mpf.mp.br/atuacao-tematica/ccr6/documentos-epublicacoes/publicacoes/mapa-da-violencia-contra-os-povos-indigenas/Relatorioviolenciacontrapovosindigenas 2017Cimi.pdf

ROSSATO, Veronice. Lovato. Territorios etnoeducacionais. in: VINHA, Marina. (Coord.). Educação Escolar Guarani e Kaiowá: Território Etnoeducacional Cone Sul. Dourados: FUNDECT/UFGD, 2015.

SOUSA, F. B. Reterritorializando a educação escolar indígena: reflexões acerca dos territórios etnoeducacionais. UFRGS, Porto Alegre, 2013. (dissertação mestrado)

SANTOS, Douglas. De volta às discussões sobre o significado de paisagem e outras avenças. Ateliê Geográfico. V.12. N.2. Goiânia, 2018. p.39-52. https://www.revistas.ufg.br/atelie/article/view/55830/26569

VINHA, M. (Coord). Educação Escolar Guarani e Kaiowá: Território Etnoeducacional Cone Sul. Dourados: FUNDECT/UFGD, 2015. 